\title{
FESTIVAL KAMPUNG SENAUNG 2017 DALAM PERSPEKTIF DEMOKRATISASI DESA
}

\author{
SENAUNG KAMPUNG FESTIVAL 2017 IN PERSPECTIVE \\ DEMOCRATIZATION OF VILLAGE
}

\author{
Wenny Ira Reverawati \\ STISIP Nurdin Hamzah \\ Jl. Kol. Abunjani, Sipin, Jambi \\ Email : wennyirareverawati@gmail.com
}

\begin{abstract}
Based on the principle of recognition of the rights of the origins of the village and the local authority in the Act Village 6 2014, the village Senaung reintegrate traditional institutions village that has become the original arrangement of village governance from time immemorial to the village government administration. However, traditional institutions still lack functioning optimally to support tasks, duties, authority of the village chief in sustainability, empowerment, development of customs and cultural traditions and social values in rural communities. In fact, if both partners and performs its function can be used as a means of developing the democratization of the village towards the socio-cultural-based development issues, then Senaung Village Festival 2017 to drive forward progress on the partnership between them in carrying out these functions. This study aimed to analyze the Senaung Village Festival 2017 in the village of democratization perspective. The method used is a qualitative descriptive studywith a case study approach, the sampling technique is purposive sampling collection and analysis of data in a holistic manner in accordance with the approach of case study research. The results of this study indicate that the Festival Village Senaung 2017 is on the agenda of preservation, empowerment and development, coaching customs, traditions and social culture in the village Senaung inadvertently awaken the mechanical solidarity of rural communities Senaung who had been threatened with a sense of individualism. This festival accommodate the history and the uniqueness of the cultural patterns of socio Senaung rural communities. In the perspective of democratization village, Kampung Senaung Festival 2017 is the initiation of the development of rural democratization. Therefore, it is necessary accompaniment remains encouraging partnerships between institutions and traditions village and the village head is necessary for the function of the authority based on the right of the origin can be run by the village.
\end{abstract}

Keyword: Festival Senaung Village 2017, village traditional institutions, democratization of the village, the principle of recognition

\begin{abstract}
Abstrak
Berdasarkan asas pengakuan terhadap hak asal-usul desa dan kewenangan lokal dalam UndangUndang Desa No.6 Tahun 2014, desa Senaung mengintegrasikan kembali lembaga adat desa yang telah menjadi susunan asli tata pemerintahan desa sejak dahulu kala ke dalam penyelenggaraan pemerintahan desa. Namun, lembaga adat desa belum berfungsi secara maksimal untuk menunjang tugas, kewajiban, kewenangan kepala desa dalam hal pelestarian, pemberdayaan, pengembangan adat istiadat dan tradisi serta nilai sosial budaya di masyarakat desa. Padahal jika keduanya bermitra dan menjalankan fungsinya dapat dijadikan sarana pengembangan demokratisasi desa terhadap isu pembangunan berbasis sosio kultural, maka diinisiasilah Festival Kampung Senaung 2017 untuk mendorong jalannya kemitraan diantara keduanya dalam menjalankan fungsinya tersebut. Penelitian ini bertujuan untuk menganalisis Festival Kampung Senaung 2017 dalam perspektif demokratisasi desa. Metode penelitian yang digunakan adalah penelitian deskriptif kualitatif dengan pendekatan studi kasus, teknik pengumpulan sampling secara purposive sampling dan analisis data secara holistik yang sesuai dengan pendekatan studi kasus dalam penelitian. Hasil penelitian ini menunjukkan bahwa Festival Kampung Senaung 2017 yang merupakan agenda pelestarian, pemberdayaan, dan pengembangan, pembinaan adat istiadat, tradisi dan sosial kebudayaan yang ada di desa Senaung secara tidak sengaja membangunkan kembali solidaritas mekanis masyarakat desa Senaung yang selama ini terancam dengan rasa individualisme. Festival ini mengakomodir sejarah serta kekhasan pola sosio budaya masyarakat desa Senaung. Dalam perspektif demokratisasi desa, Festival Kampung Senaung 2017 merupakan inisiasi dari pengembangan demokratisasi desa. Saran Maka dari itu, perlu pendampingan yang tetap mendorong kemitraan
\end{abstract}


antara lembaga adat desa dan kepala desa sangat diperlukan agar fungsi kewenangan berdasarkan hak asal-usul dapat dijalankan oleh desa.

Keyword : Festival Kampung Senaung 2017, lembaga adat desa, demokratisasi desa, asas pengakuan

\section{PENDAHULUAN}

Sejak resmi diputuskan sebagai sebuah kebijakan negara yang menaungi entitas hukum bernama desa pada awal tahun 2014 lalu, Undang-Undang Desa (UU Desa) No.6 Tahun 2014 membawa perubahan tafsir dan paradigma terhadap desa yang selama ini hanya menjadi objek dan kepanjangan tangan kekuasaan pemerintah di tingkat lokal. Perubahan tersebut berdampak pada penyelenggaraan pemerintahan desa di tingkat lokal dan penanganannya di tingkat pusat.

Tata kelola desa dalam hal ini sebagaimana diamanatkan oleh UU Desa, tak lagi ditata secara seragam, sentralistik, birokratis dan objektif. Namun, desa kian berbenah untuk ditata secara partisipatif, perencanaannya disusun berdasarkan aspirasi masyarakat dari setiap lapisan sosial, tingkatan, gender, dan kelompok lainnya, serta inovatif dan mengedepankan kekhasan masing-masing desa dari segi kekayaan, potensi serta kearifan lokal yang dimiliki. Hal ini sebagaimana tertuang ke dalam asas pengaturan dan penyelenggaraan pemerintah desa dalam UU Desa.

Baik asas pengaturan desa pada pasal 3 UU Desa, maupun asas penyelenggaraan pemerintah desa pada pasal 24 dalam UU Desa, keduanya merupakan asas yang ingin mewujudkan desa ke dalam suatu bentuk tata pemerintahan di tingkat lokal yang sesuai dengan tata pemerintahan yang baik, namun mengedepankan pada keragaman serta kekhasan yang dimiliki oleh masingmasing desa. Sebab keragaman serta kekhasan desa tersebut telah menjadi riwayat penyelenggaraan pemerintahan desa di Indonesia sejak dahulu kala.

Sebagaimana juga tercantum dalam pasal 18 B Undang-Undang Dasar (UUD) 1945 ayat (1) yang menyebutkan bahwa Negara mengakui dan menghormati satuansatuan pemerintahan daerah yang bersifat khusus atau bersifat istimewa yang diatur dengan undang-undang, dan ayat (2) Negara mengakui dan menghormati kesatuan-kesatuan masyarakat hukum adat beserta hak-hak tradisionalnya sepanjang masih hidup dan sesuai dengan perkembangan masyarakat dan prinsip Negara Kesatuan Republik Indonesia, yang diatur dalam undang-undang.

Pasal dalam UUD 1945 di atas merupakan fakta hukum bahwa terdapat keragaman dan sifat keaslian pada tata pemerintahan desa yang ada di Indonesia. Keragaman dan keaslian tersebut diakui secara hukum oleh pemerintahan Republik Indonesia, maka sudah selayaknya dalam penyelenggaraan pemerintahannya juga diberlakukan untuk mengedepankan prinsip keragaman dan pengakuan terhadap hak 
asal-usul yang melekat pada desa, bukan justru sebaliknya memberlakukan secara seragam terhadap penyelenggaraan pemerintahan desa, sebagaimana yang pernah dilakukan selama tiga puluh dua tahun oleh orde baru.

Oleh karena itulah, UU Desa mencantumkan asas pengakuan terhadap hak asal usul desa (rekognisi) sebagai bentuk pengakuan dan penegasan dalam pengaturan desa yang memiliki hak asalusul berupa sistem pemerintahan, tata cara, adat istiadat, institusi, kebiasaan yang asli dan melekat pada desa jauh sebelum Negara Kesatuan Republik Indonesia (NKRI) terbentuk. Asas ini ditunjang dengan asas penyelenggaraan pemerintahan desa dalam UU Desa yaitu kearifan lokal, keberagaman dan partisipatif.

Selama orde baru berkuasa, kelompok-kelompok adat dan lembaga adat yang menjadi susunan asli desa-desa di Indonesia dibungkam serta dipinggirkan dari pusat aktivitas tata pemerintahan desa. Perannya hanya difungsikan dalam penyelesaian sengketa masalah sosial masyarakat desa yang membutuhkan sanksi hukum adat, tidak lebih dari itu.

Upaya pembungkaman dan peminggiran ini menyebabkan rusaknya tatanan adat istiadat, punahnya tradisi dan budaya yang ada pada masyarakat desa, tersingkirnya kelompok minoritas adat dalam pelayanan dan pembangunan. Sebab selama itu pula desa hanya difokuskan untuk memenuhi kepentingan penguasa dan elit politik yang ada. Untuk itu lah UU Desa berupaya menata kembali tatanan asli desa agar selaras dan berkembang menunjang pembangunan yang merata tanpa adanya diskriminasi.

UU Desa pun memberikan hak kepada desa untuk mengatur kepentingannya berdasarkan hak asalusulnya, apakah itu berupa adat istiadat atau nilai sosial budaya kemasyarakatan lainnya. Lembaga adat desa pun mendapat tempat sebagai institusi asli yang diakui secara hukum dalam UU Desa untuk terlibat ke dalam penyelenggaraan pemerintahan desa. Kepala desa dan lembaga adat dalam pengaturan mengenai hak asal-usul ini kemudian oleh UU Desa diamanatkan untuk saling bermitra dalam melestarikan dan memberdayakan adat istiadat, sosial dan budaya masyarakat desa.

Menimbang pada hal tersebut diatas, tim Rural Community Development (RCD) "Bergerak Membangun Desa" Lembaga Penelitian dan Pengabdian Masyarakat (LPPM) STISIP Nurdin Hamzah Jambi, melakukan upaya observasi, penelitian dan pendampingan terhadap tugas kepala desa serta lembaga adat desa dalam melestarikan dan memberdayakan adat istiadat, sosial dan budaya masyarakat desa sebagaimana tercantum dalam UU Desa pasal 26 mengenai tugas dan kewajiban kepala desa serta pasal 95 mengenai lembaga adat desa.

Observasi yang dilakukan di desa Senaung, kecamatan Jambi Luar Kota, 
kabupaten Muaro Jambi, Provinsi Jambi pada kurun waktu September hingga November 2017 menunjukkan bahwa, desa Senaung memiliki susunan asli pemerintahan desanya berupa adanya lembaga adat desa. Namun, baik kepala desa maupun lembaga adat desa belum sepenuhnya melakukan fungsi dan tugas untuk mengembangkan, melestarikan dan memberdayakan adat istiadat, tradisi dan nilai sosial budaya pada masyarakat.

Lembaga adat hanya meneguhkan kedudukannya dalam penyelesaian sengketa masyarakat secara adat, meskipun strukturnya ada dalam pemerintahan desa. Kepala desa hanya memberikan insentif honorarium kepada struktur lembaga adat. Sementara itu terdapat masalah di masyarakat berupa minimnya regenerasi tokoh adat, terancam punahnya tradisi, adat istiadat serta nilai sosial budaya di masyarakat mengingat posisi desa Senaung yang berada di wilayah urban peripheral kota Jambi dan rawan terhadap ancaman perubahan serta modernisasi (LPPM STISIP Nurdin Hamzah, 2017).

Maka, untuk mendorong tugas dan fungsi kepala desa yang bermitra dengan lembaga adat desa dalam pelestarian, pengembangan dan pemberdayaan adat istiadat, tradisi serta nilai sosial budaya di inisiasi Festival Kampung Senaung 2017. Festival ini untuk menginisiasi lembaga adat desa dan kepala desa Senaung dalam mengembangkan, tugas dan fungsinya tersebut sekaligus menjadikan isu pelestarian dan pemberdayaan di bidang adat istiadat, tradisi serta budaya menjadi bagian dari perencanaan pembangunan desa.

Upaya ini penting mengingat bahwa adat istiadat, tradisi dan budaya merupakan benteng ketahanan terakhir suatu masyarakat dalam menghadapi perubahan yang terjadi. Sekaligus sebagai upaya untuk mendorong tumbuhnya demokratisasi desa yang berbasis pada sosio kultur masyarakat untuk menopang ketahanan desa dan masyarakat sebagaimana diamanatkan oleh UU Desa. Ini mengingat dan menimbang pada ancaman serta tantangan yang dihadapi oleh desa dan masyarakat Senaung terhadap perubahan dan modernisasi dari kota Jambi dan sekitarnya. Berdasarkan laporan observasi dan tindak lanjut dari tim RCD LPPM STISIP Nurdin Hamzah tersebut, penulis tertarik untuk melakukan penelitian terhadap Festival Kampung Senaung 2017 ditinjau dari perspektif demokratisasi desa yang dikandung dalam UU Desa. Penelitian ini bertujuan untuk menganalisis bagaimanakah Festival Kampung Senaung 2017 dalam perspektif demokratisasi desa terhadap inisiasi pembangunan desa berbasis isu budaya.

\section{METODE PENELITIAN}

Penelitian ini menggunakan metode penelitian kualitatif dengan menggunakan pendekatan studi kasus pada agenda Festival Kampung Senaung 2017 untuk dapat mengkajinya secara mendalam 
dengan perspektif demokratisasi desa. Data yang digunakan yaitu data primer hasil observasi dan wawancara serta data sekunder pada dokumen-dokumen penunjang seperti buku, jurnal, internet, perundang-undangan dan lain-lainnya. Data dikumpulkan dengan menggunakan dokumen, hasil observasi, dan wawancara.

Teknik pengambilan sampling dilakukan dengan menggunakan purposive sampling. Maka dari itu, yang menjadi responden dalam penelitian ini dipilih dengan kriteria tertentu yang mengetahui mengenai selukbeluk hak asal-usul, adat-istiadat, tradisi dan agenda Festival Kampung Senaung 2017. Adapun yang menjadi responden dalam penelitian ini yaitu ;

1. Kepala desa Senaung.

2. Ketua lembaga adat desa Senaung

3. Tiga orang anggota lembaga adat desa Senaung.

4. Empat orang pelaku seni tradisi desa Senaung

5. Empat orang peserta Senaung Berseloko

Analisis data dalam penelitian ini menggunakan langkah-langkah analisis sebagai berikut :

1. Mengorganisir informasi yang terkait dengan Festival Kampung Senaung 2017.

2. Membaca keseluruhan informasi yang terkait dengan Festival Kampung Senaung 2017.

3. Membuat suatu uraian terperinci mengenai agenda Fetsival Kampung
Senaung 2017 dan konteksnya dengan pelaksanaan Undang-Undang Desa (UU Desa) sNo. 6 Tahun 2014 dan demokratisasi desa.

4. Menetapkan pola agenda Festival Kampung Senaung 2017 dan kaitannya dengan demokratisasi desa serta UU Desa.

5. Melakukan interpretasi dan mengembangkan generalisasi natural dari agenda Festival Kampung Senaung 2017

6. Menyajikan secara naratif Festival Kampung Senaung 2017 dalam perspektif demokratisasi desa

\section{HASIL DAN PEMBAHASAN}

Perbedaan dari UU Desa dan undang-undang sebelumnya yang berusaha mengatur desa adalah dikenalnya asas rekognisi sebagai asas pengaturan desa. Asas ini sebagaimana tercantum pada pasal 3 dan dijelaskan pada pasal 4 UU Desa bertujuan untuk memberikan pengakuan dan penghormatan atas Desa yang sudah ada dengan keberagamannya sebelum dan sesudah terbentuknya Negara Kesatuan Republik Indonesia (NKRI).

Maka, saat ini desa yang memiliki riwayat historis akan susunan pemerintahan serta kelembagaan aslinya yang dapat saja berupa tatanan pemerintahan adat, lembaga adat, mekanisme adat, serta nilainilai tradisi dan sosial budaya yang telah melekat padanya dan masih digunakan hingga sekarang, diakui dan dihormati oleh pemerintahan NKRI secara hukum. Desa 
pun dapat memilih untuk menggunakan keasliannya tersebut sebagai identitas atau tidak dalam penyelenggaraan pemerintahan desa.

Salah satu bagian terpenting dalam UU Desa adalah pengakuan Negara terhadap hak asal-usul desa dan penetapan kewenangan berskala lokal dan pengambilan keputusan secara lokal untuk kepentingan masyarakat desa. Dengan dua asas tersebut, desa memiliki kewenangan yang sangat besar untuk mengurus dirinya sendiri(Amanulloh, 2015)

Adanya pengakuan terhadap hak asal-usul desa ini merupakan angin segar bagi kelompok minoritas adat dan kelembagaan adat desa yang selama tiga puluh dua tahun lebih orde baru berkuasa dibungkam dan disingkirkan. Selama tiga puluh dua tahun itu pula, lembaga adat dan kelompok adat dilemahkan fungsinya hanya sebagai lembaga yang hanya menangani masalah sosial kemasyarakatan baik yang bersifat individu, kekeluargaan maupun kelompok. Sedangkan aslinya mereka merupakan bagian dari isntitusionalisasi penyelenggaraan pemerintahan desa sejak dahulu(JAMBI, 2009).

Untuk itu, tak hanya memberikan asas rekognisi, UU Desa juga memberikan kepada desa hak untuk mengatur dan mengurus kepentingan masyarakat berdasarkan hak asal usul, adat istiadat, dan nilai sosial budaya masyarakat desa sebagaimana tercantum pada pasal 67 .

Lebih lanjut UU Desa juga mempertegas hal ini dengan memberikan kewenangan kepada desa berupa kewenangan berdasarkan hak asal-usul.

Desa Senaung berdasarkan hasil observasi tim RCD LPPM STISIP Nurdin hamzah, memiliki susunan asli dalam tata pemerintahan desanya yaitu berupa adanya lembaga adat desa. Lembaga adat desa ini telah sejak dari dahulu kala menjadi bagian dari sistem pemerintahan desa yang dikenal dengan istilah tigo tali sepilin, tigo tungku sejerangan. Istilah ini merujuk kepada tiga unsur dalam tata pemerintahan desa Senaung yang asli dan tidak dapat dipisahkan dalam membuat keputusan, penyelesaian masalah kemasyarakatan dan fungsi-fungsi pemerintahan lainnya.

Tiga unsur tersebut antara lain, yaitu kepala desa atau kepala kampung, tokoh adat dan cerdik pandai atau alim ulama. Tiga unsur ini dengan menggunakan mekanisme musyawarah dan mufakat menjalankan roda pemerintahan desa, dan sebagai unsur kepemimpinan yang harus dipedomani. Namun, sejak penerapan kebijakan orde baru melalui UndangUndang No.5 Tahun 1979, tiga unsur ini dicerabut dari akar historisnya.

Sebab pada masa pemerintahan orde baru yang menginginkan keseragaman dan sistem birokratis militeristik, hanya kepala desa yang dianggap sebagai pemimpin dalam penyelenggaraan pemerintahan desa. Dua unsur yang lainnya disisihkan hanya sebatas penyelesaian sengketa kemasyarakatan secara adat semata dan tugas-tugas keagamaan. Hasilnya dapat dilihat pada 
lembaga adat desa yang apatis dalam penyelenggaraan pemerintahan desa dan pelaksanaan demokratisasi desa.

Sejak diberlakukannya UU Desa pada tahun 2014, lembaga adat desa kembali diangkat ke dalam bagian penyelenggaraan pemerintahan desa Senaung. Namun, belum banyak yang dapat dilakukan oleh lembaga adat desa kecuali sebatas pada masalah pranata adat dan penyelesaian sengketa kemasyarakatan secara adat. Sementara itu, di dalam tubuh lembaga adat desa sendiri mengalami degenerasi ketokohan adat serta pengembangan dan pelestarian adat istiadat desa Senaung.

Kondisi yang demikian ini, dianggap menjadi ancaman bagi keberlangsungan lembaga adat desa Senaung(Wawancara dengan Kkepala Desa Senaung Mengenai Kondisi Lembaga Adat Desa Senaung, 2017). Sebab jika tidak ada upaya mengatasi degenarasi yang terjadi, maka pengembangan dan pelestarian adat istiadat desa Senaung juga turut terancam menuju kepunahan. Upaya ini patut untuk dijadikan rujukan untuk mengembalikan identitas serta ciri khas yang dimiliki oleh desa Senaung sebagai sebuah entitas.

Mengingat eksistensi lembaga adat desa tersebut juga berperan dalam mempertahankan kearifan lokal yang telah ada. Kearifan lokal tersebut yang pertama tercermin kedalam bentuk-bentuk seloko adat (ungkapan adat) untuk kepemimpinan, hubungan kemasyarakatan, pranata adat pernikahan, musyawarah, penyelesaian sengketa kemasyarakatan, dan lainnya.

Berikutnya banyak ditemukan kearifan lokal dalam bentuk pengetahuan tradisional, teknologi tradisional, seni, tradisi lisan, bahasa, adat istiadat, manuskrip, permainan rakyat dan olahraga tradisional (Kumpulan Hasil Wawancara dengan Masyarakat Senaung Tentang Objek Pemajuan Kebudayaan, 2017). Lembaga adat dalam hal ini memiliki potensi untuk lebih mengembangkan kearifan lokal tersebut agar tidak tergerus dengan perubahan jaman dan bersama kepala desa untuk lebih mengupayakannya menjadi isu dalam pembangunan desa melalui pelestarian, pemberdayaan dan pengembangan.

Inilah yang belum tampak pada desa Senaung sebagaimana asas keberagaman dan kearifan lokal dalam pengaturan serta penyelenggaraan pemerintahan desa Pasal 3 dan pasal 24 UU Desa amanatkan. Asas keberagaman mensyaratkan

penyeleng-garaan pemerintah desa yang tidak boleh mendiskriminasi kelompok tertentu dalam hal ini jika diterapkan di desa Senaung adalah kelompok adat dan pelaku tradisi tidak boleh didiskriminasi dalam penyelenggaraan pemerintahan desa. Mereka harus menjadi bagian yang diperhatikan dalam penyelenggaraan pemerintahan desa.

Kelompok adat dan pelaku tradisi yang ada di desa Senaung cenderung belum masuk kedalam bagian perencanaan pembangunan dalam penyelenggaraan 
pemerintahan desa Senaung. Mengingat hasil observasi tim RCD menunjukkan adanya beragam tradisi lisan, tradisi yang menjadi bagian adat -istiadat berwujud warisan budaya tak benda yang dapat menjadi potensi bagi desa Senaung untuk menggalakkan pembangunan melalui isu budaya.

Sedangkan asas kearifan lokal mensyaratkan penyelenggaraan pemerintahan desa harus memperhatikan kebutuhan dan kepentingan masyarakat desa dalam penetapan kebijakan. Mempertimbangkan kepada kebutuhan dan kepentingan kelompok adat dan pelaku tradisi yang ada di desa Senaung dalam menjaga kearifan lokal berupada adat istiadat, tradisi dan nilai sosial budaya, yang belum tersentuh langkah pelestarian, pengembangan dan pemberdayaan. Sementara itu pelaku tradisi dan kekayaan tradisi yang mereka punyai ada diambang ancaman kepunahan tergerus perubahan dan modernisasi.

Ancaman kepunahan karena perubahan dan modernisasi yang tak terelakkan pada pemerintahan desa dan masyarakat desa Senaung dari segi budaya, tradisi dan nilai sosial budaya, datang pada kondisi geografis desa yang berada di pinggir jalan lintas Jambi dan merupakan urban peripheral, lokasi yang mendukung kebutuhan kota Jambi untuk berkembang. Ancaman untuk perubahan gaya hidup dan pembangunan daya dukung perkotaan telah mengikuti perkembangan mereka.
Modernisasi tak terelakkan pada masyarakat desa Senaung. Pilihannya menjadi bentuk masyarakat modern yang menguasai tempat dan entitas mereka berkembang atau justru tergusur. Beberapa tradisi punah karena pemuda lebih memilih bekerja di pabrik terdekat desa, selain tradisi regenerasi ketokohan adat juga seperti tradisi beselang yang dahulu banyak diramaikan pemuda dan pemudi desa ketika turun membersihkan sawah. Begitu juga dengan rebana Siam, seni berdzikir yang menggunakan alat musik rebana. Sebab generasi sekarang lebih memilih seni kompangan modern yang telah dimodifikasi.

Desa Senaung dalam hal ini memiliki banyak potensi kewenangan lokal yang menjadi urusannya dan belum dilaksanakan, sebagaimana ditetapkan dalam Peraturan Menteri Desa (Permendes) No.1 Tahun 2015 Tentang Pedoman Kewenangan Berdasarkan Hak Asal-Usul dan Kewenangan Berskala Lokal, yang mana peraturan ini mengacu pada pasal 18 dan 19 UU Desa tentang Kewenangan Desa.

Adapun ruang lingkup kewenangan hak asal-usul berdasarkan Permendes No.1 Tahun 2015 yang dapat dijadikan pedoman oleh desa Senaung antara lain dalam hal sistem organisasi masyarakat adat dan perangkat desa, pembinaan kelembagaan masyarakat, pembinaan hukum adat, serta pengembangan peran masyarakat desa. Beberapa ruang lingkup tersebut belum diupayakan maksimal untuk menguatkan 
entitas desa Senaung sebagai desa yang memiliki identitas yang khas dan memiliki riwayat historis.

Masyarakat desa Senaung belum berperan maksimal dalam mengembangkan dan melestarikan tradisi, adat istiadat dan nilai sosial budaya yang menjadi warisan mereka. Perubahan jaman dan arus modernisasi menyebabkan sebagian besar mereka abai terhadap hal tersebut terutama generasi muda. Hukum adat, organisasi masyarakat adat dan perangkat desa tengah diupayakan dilakukan pembinaan melalui bimbingan teknis kelembagaan adat yang diadakan oleh provinsi Jambi. Sedangkan pembinaan kelembagaan masyarakat belum maksimal untuk pelaku tradisi dan kelembagaan lain yang mengembangkan pranata adat setempat.

Upaya untuk mengedepankan asas rekognisi, keberagaman, kearifan lokal serta memajukan kewenangan berdasarkan hak asal-usul pada desa Senaung, tidak bisa dilakukan sendiri oleh pemerintah desa. UU Desa memberikan pedoman pada pasal 26 ayat (1) mengenai tugas, kewenangan dan kewajiban kepala desa yaitu bahwa kepala desa bertugas menyelenggarakan Pemerintahan Desa, melaksanakan Pembangunan Desa, pembinaan kemasyarakatan Desa, dan pemberdayaan masyarakat Desa.

Untuk itu, salah satu yang menjadi kewenangannya yaitu mengembangkan kehidupan sosial budaya masyarakat desa sebagaimana tercantum pada pasal 26 ayat (2). Kewajiban kepala desa terhadap hal ini tercantum pada pasal 26 ayat (4) salah satunya yaitu bahwa kepala desa berkewajiban untuk membina dan melestarikan nilai sosial budaya masyarakat Desa. Sedangkan kewenangan kepala desa pada pasal 26 ayat (2) yaitu mengembangkan kehidupan sosial budaya masyarakat desa.

Tugas, kewenangan dan kewajiban kepala desa sebagaimana ditentukan pada UU Desa tersebut seiring dengan tugas lembaga adat desa yang tercantum pada pasal 95 ayat (3) yang menyebutkan bahwa Lembaga adat Desa bertugas membantu Pemerintah Desa dan sebagai mitra dalam memberdayakan, melestarikan, dan mengembangkan adat istiadat sebagai wujud pengakuan terhadap adat istiadat masyarakat Desa .

Kepala desa dan lembaga adat desa dalam hal ini dapat menjadi mitra dalam mengembangkan, melestarikan dan memberdayakan adat istiadat dan nilai sosial budaya masyarakat desa. Kepala desa Senaung dalam hal ini pada hasil observasi tim RCD LPPM STISIP Nurdin Hamzah, belum menunjukkan upaya maksimal dalam menjalanlan tugas, kewajiban, kewenangannya terhadap pelestarian, pengembangan, pemberdayaan dan pembinaan kehidupan sosial budaya masyarakat desa.

Kerjasama antara kepala desa dan lembaga adat desa dalam bidang tersebut pun masih belum maksimal. Kecuali dalam pelaksanaan pranata adat pernikahan, penyambutan tamu dan penyelesaian 
sengketa masalah kemasyarakatan. Bidang ini belum tersentuh karena pemerintahan desa tengah fokus kepada masalah administrasi dan birokrasi serta pembangunan fisik lainnya. Kecenderungan pembangunan fisik yang menyebabkan isuisu sosial kebudayaan pada pembangunan desa Senaung belum menjadi perhatian. Lembaga adat desa hanya menjadi pelengkap pada pemerintahan desa dan menjalankan fungsinya bagi penyelesaian sengketa masalah kemasyarakatan. Sedangkan dalam pembangunan desa yang meliputi perencanaan, pelaksanaan dan pengawasan, lembaga adat hanya sebatas hadir pada pertemuan-pertemuan dan permufakatan yang ada.

Maka tak heran jika isu-isu sosial kebudayaan pada pembangunan desa Senaung menjadi terpinggirkan termasuk masalah degenerasi tokoh adat, dan ancaman kepunahan tradisi serta budaya yang ada. Atas dasar tersebut, tim RCD LPPM STISIP Nurdin Hamzah melakukan inisiasi untuk mendorong kemitraan antara kepala desa Senaung dan lembaga adat desa dalam mengedepankan isu-isu sosial kebudayaan pada pembangunan desa melalui penyelenggaraan Festival Kampung Senaung 2017(Mapping Festival Kampung Senaung 2017, 2017).

Festival Kampung Senaung 2017 merupakan agenda pelestarian, pemberdayaan, dan pengembangan, pembinaan adat istiadat, tradisi dan sosial kebudayaan yang ada di desa Senaung. Melalui festival ini, selain mendorong kemitraan antara kepala desa dan lembaga adat desa, juga untuk mendorong partisipasi masyarakat desa dalam mengedepankan isu-isu sosial kebudayaan sebagai benteng terakhir ketahanan masyarakat untuk menahan dari pengaruh yang masuk dan dapat merusak tatanan serta modal sosial yang ada.

Adanya inisiasi Festival Kampung Senaung 2017 ini, kemudian mencetuskan ide bagi kepala desa dan lembaga adat desa Senaung untuk juga menyisipkan acara Senaung Berseloko dalam rangka meregenerasi pelaku seloko dalam pranata adat pernikahan. Senaung berseloko merupakan lomba berseloko untuk pranata adat pernikahan yang digelar demi mencari pemenang yang direkrut untuk menjadi bagian lembaga adat dalam pelaksanaan pranata adat tersebut.

Agenda dari Festival Kampung Senaung 2017 yang diadakan pada tanggal 22 hingga 26 November 2017, bertempat di desa Senaung, melibatkan kepala desa, lembaga adat desa, perangkat desa, ulama, pelaksana kewilayahan desa, pelaku seni dan tradisi, perempuan dan anak, tim pendamping RCD LPPM STISIP Nurdin Hamzah, media, tokoh budaya dan masyarakat luas. Adapun agenda dari festival adalah sebagai berikut ;

Rabu, 22 November 2017, bertempat di kantor desa Senaung diadakan acara diskusi pemajuan kebudayaan bersama tokoh budaya dan pelaku budaya Provinsi Jambi, kepala desa, perangkat desa, pelaksana kewilayahan desa, pelaku tradisi. 
Selesai diskusi dilakukan pembukaan sekaligus tour benda dan arsitektur bersejarah desa Senaung.

Kamis, 23 hingga 26 November 2017, dibuka tour benda dan arsitektur bersejarah desa Senaung yang mengambil tempat perumahan warga sebagai lokasi museum sementara. Pemandu tour dalam hal ini tim pendamping RCD LPPM STISIP Nurdin Hamzah dan warga desa Senaung,

Jumat, 24 November 2017, dilakukan pembukaan Festival Kampung Senaung 2017 dan Senaung Berseloko. Pada pembukaan ini ditampilkan seni tradisi yang hampir punah seperti kesenian rebana Siam, pencak silat melayu, arak-arakkan menggunakan rebana Siam, dan kompangan modern.

Sabtu, 25 November 2017 , dilakukan pertunjukan beselang di sawah yang menampilkan tradisi berpantun dan perkenalan muda-mudi ketika membersihkan sawah

- Minggu, 26 November 2017, dilaksanakan lomba Senaung Berseloko

Festival Kampung Senaung 2017 berangkat dari sejarah dan kekhasan pola sosio budaya yang dimiliki oleh masyarakat desa Senaung. Ini terlihat pada upaya pendampingan kemitraan antara kepala desa, lembaga adat dan ulama serta cerdik pandai dalam musyawarah-musyawarah menjelang festival diadakan. Terdapat enam kali musyawarah yang melibatkan mereka bersama masyarakat dan kelompok perempuan untuk menentukan konsep, ide, rencana maupun pelaksanaan festival. Mereka yang terlibat mendukung upaya pelestarian adat istiadat, tradisi, dan nilai sosial budaya kemasyarakatan melalui festival. Hasilnya mereka merekomendasikan agar agenda tetap berkesinambungan untuk dijalankan (Kumpulan Notulensi Musyawarah Festival Kampung Senaung 2017, 2017).

Musyawarah-musyawarah yang diadakan tersebut menginisiasi perkembangan demokrasi lokal di tingkat desa untuk mengedepankan basis sosio kultural masyarakat agar dapat menjadi bagian dari perencanaan pembangunan desa ke depannya. Karena di dalamnya terpetakan permasalahan isu sosial budaya yang menyangkut kewenangan berdasarkan hak asal-usul, tugas kepala desa dan lembaga adat serta peran serta masyarakat dan penerapan asas keberagaman serta kearifan lokal.

Pada musyawarah ini sifat kolektivitas yang dimiliki oleh masyarakat desa Senaung digali dan dimunculkan kembali untuk memupuk modal sosial melalui isu-isu sosial kebudayaan dalam penyelenggaraan Festival Kampung Senaung 2017. Dan ini terbukti dengan intensitas musyawarah untuk mencapai mufakat dalam agenda festival. Selain kolektivitas, musyawarah yang terjadi menunjukkan partisipasi aktif masyarakat 
desa dalam menangani kepentingan masyarakat desa melalui festival.

Kepemimpinan kepala desa Senaung yang dipegang oleh tokoh muda , serta merta tidak merusak tatanan tradisi yang ada. Sebab justru kepala desa ini yang menjadi mediator sekaligus fasilitator bagi unsur-unsur lainnya yang hadir dalam musyawarah. Kepala desa sangat menghormati tuo tengganai yang ada. Justru apa yang dilakukannya sebagai mediator maupun fasilitator dapat menumbuhkan peran aktif unsur lainnya.

Festival Kampung Senaung 2017 secara tidak sengaja membangunkan kembali solidaritas mekanis masyarakat desa Senaung yang selama ini terancam dengan rasa individualisme. Bahu membahu warga desa menopang pelaksanaan festival dalam bentuk gotong royong, persiapan maupun pelaksanaan acara, meskipun solidaritas ini hanya baru dilaksanakan oleh sebagian kelompok seperti perkumpulan ibu Rukun Tetangga, bapak Rukun tetangga, dan perangkat desa serta kepala dusun yang ada. Pada agenda festival ini, mereka diinisiasi untuk menjadi subjek yang menentukan sendiri bagaimana pembangunan desanya direncanakan dan dilaksanakan, dan merekalah yang mejadi aktor utama, bukan orang luar.

Mengedepankan konsep keterikatan terhadap ruang dan hubungan personal yang dimiliki oleh masyarakat desa Senaung, Festival Kampung Senaung 2017 diadakan di desa Senaung itu sendiri. Bukan dengan cara memindahkan pertunjukkan tradisi ke tempat lain. Beberapa agenda festival seperti beselang misalnya menunjukkan pola keterikatan dengan ruang oleh masyarakat desa Senaung dalam menghormati tanah. Disamping itu, pemilihan lokasi festival yang telah mereka tentukan yaitu berada di arena masjid besar yang dibangun sejak tahun 1853 memunculkan kembali keterikatan masyarakat setempat terhadap kenangan akan kegunaan ruang dan lokasi masjid sebagai ruang utama pada jaman dahulu kala.

Lokasi festival pada halaman masjid dan beberapa arsitektur yang dipamerkan berada di pinggir sungai Batanghari, dan dahulu pinggiran sungai merupakan bentuk keterikatan masyarakat desa setempat pada arti moda serta kehidupan pinggir sungai yang kini perlahan mereka tinggalkan berganti menjadi moda kehidupan darat. Namun kehidupan pinggir sungai Batanghari ini masih menjadi ciri khas tersendiri

Dari agenda Festival Kampung Senaung 2017 juga dapat dilihat bahwa festival mengakomodir sejarah serta kekhasan pola sosio budaya masyarakat desa Senaung yang selama ini telah ada, kemudian dikemas dalam bentuk pertunjukkan dan pameran agar masyarakat luas mendapat informasi mengenai budaya dan sejarah Senaung. Melalui festival ini, Senaung ditampilkan sebagi entitas yang memiliki ciri khas tersendiri dan berpotensi untuk dikembangkan lebih lanjut dalam 
pembangunan desa yang mengedepankan prinsip demokrasi.

Berlatar belakang pada asas pengakuan terhadap hak asal-usul dan kewenangan lokal pada UU Desa, Festival Kampung Senaung 2017 dilaksanakan. Pada festival ini dan Senaung Berseloko hak asal-usul desa Senaung dikedepankan untuk didorong menjadi bagian dari isu pembangunan desa, yang ternyata menadapat respon positif baik dari kepala desa maupun lembaga adat desa serta unsur lainnnya. Meskipun baru pada tahap inisiasi, namun festival ini telah berhasil mendorong desa Senaung untuk melaksanakan sebagai self governing community yang memiliki kapasitas untuk mengatur dirinya sendiri dalam pengembangan, pelestarian, dan rencana pemberdayaan adat istiadat serta nilai sosial budaya.

Maka dalam perspektif demokratisasi desa, Festival Kampung Senaung 2017 merupakan inisiasi dari pengembangan demokratisasi desa. Pengembangan tersebut didorong dengan mengedepankan isu budaya dalam pembangunan desa yang berasal dari kekayaan tradisi sesuai dengan asalusulnya, dan pola sosio budaya masyarakat desa Senaung. Inisiasi festival ini tumbuh dari pergulatan masyarakat desa Senaung yang mulai menyadari keresahannya akan modal sosial kekayaan dan pola sosio budaya tersebut yang saat ini mulai terancam tergerus perubahan dan arus modernisasi.
Sebagaimana pelaku tradisi pada tradisi beselang maupun rebana Siam serta beberapa pemilik benda dan arstitektur juga lembaga adat desa mengatakan bahwa kekayaan tradisi, adat istiadat serta budaya di desa Senaung saat ini mulai perlahan ditinggalkan karena kemajuan jaman dan karena adanya pabrik di dekat desa yang menyebabkan pemuda-pemudi tak lagi hirau akan tradisi desa setempat terutama pada tradisi beselang maupun rebana Siam (“Kumpulan Wawancara dengan Pelaku Seni dan Tradisi Desa Senaung," n.d.).

Festival Kampung Senaung 2017 dalam perspektif demokratisasi desa yang berbasiskan pada sosio kultural desa, selain merupakan inisiasi pengembangan demo-kratisasi desa yang menampakkan keberagaman, juga menunjukkan bahwa sebagai sebuah entitas hukum, desa Senaung merupakan subjek yang harus dihargai potensi keberagaman, kekayaan tradisi serta kearifan lokal yang berkembang di dalamnya. Masyarakat desanya bertumbuh menjadi aktor yang dapat membantu pelaksanaan demokratisasi desa yang inklusif bersama elit pemerintahan yang ada. Ini yang membedakan Senaung dengan desa lainnya, disamping itu upaya inisiasi melalui festival ini juga menunjukkan bahwa basis sosio kultural desa Senaung yang telah ada dapat menjadi modal sosial dan pintu masuk bagi pembangunan desa dan masifnya demokratisasi desa lebih lanjut. 


\section{Kesimpulan}

Kesimpulan dari penelitian ini adalah :

1. Festival Kampung Senaung 2017 merupakan agenda pelestarian, pemberdayaan, dan pengembangan, pembinaan adat istiadat, tradisi dan sosial kebudayaan yang ada di desa Senaung

2. Festival Kampung Senaung 2017 secara tidak sengaja membangunkan kembali solidaritas mekanis masyarakat desa Senaung yang selama ini terancam dengan rasa individualisme

3. Agenda Festival Kampung Senaung 2017 dapat dilihat sebagai festival yang mengakomodir sejarah serta kekhasan pola sosio budaya masyarakat desa Senaung

4. Dalam perspektif demokratisasi desa, Festival Kampung Senaung 2017 merupakan inisiasi dari pengembangan demokratisasi desa

\section{Saran}

Adapun yang menjadi saran dalam penelitian ini yaitu ;

1. Perlu dilakukan upaya berkelanjutan dan pendampingan untuk mendorong kemitraan kepala desa dan lembaga adat desa dalam mengedepankan asas rekognisi dan subsidiaritas untuk menjalankan kewenangan berdasarkan hak asal-usul dan kewenangan berskala lokal desa, salah satunya melalui bentuk agenda Festival Kampung.
2. Upaya tersebut harus tetap memperhatikan keberagaman dan kearifan lokal yang ada sehingga demokratisasi desa memang secara masif bertumbuh di tingkat desa, desa dan masyarakat desa pun selanjutnya memiliki kekuatan serta kapasitas sebagai entitas hukum di tingkat lokal.

\section{DAFTAR PUSTAKA}

Amanulloh, N. (2015). Demokratisasi Desa: Kementerian Desa, Pembangunan Daerah Tertinggal, Dan Transmigrasi Republik Indonesia.

JAMBI, L. A. M. (2009). HIMPUNAN MATERI Pembekalan Adat Istiadat Melayu Jambi Bagi Perangkat Desa Dan Lembaga Adat Desa Dalam Provinsi Jambi Angkatan Ke-XII 24 S/D 28 Mei 2009. Jambi.

Kumpulan Hasil Wawancara dengan Masyarakat Senaung Tentang Objek Pemajuan Kebudayaan (2017).

Kumpulan Notulensi Musyawarah Festival Kampung Senaung 2017. (2017).

Kumpulan Wawancara dengan Pelaku Seni dan Tradisi Desa Senaung. (n.d.).

LPPM STISIP Nurdin Hamzah. (2017). Hasil Observasi Tim Pendampingan Festival Kampung Senaung 2017 (Laporan Observasi No. 7).

Mapping Festival Kampung Senaung 2017. (2017).

Wawancara dengan Kkepala Desa Senaung Mengenai Kondisi Lembaga Adat Desa Senaung (2017).

Undang-Undang No.6 Tahun 2014 Tentang Pemerintahan Desa

Peraturan Menteri Desa (Permendes) No.1 Tahun 2015 Tentang Pedoman Kewenangan Berdasarkan Hak AsalUsul dan Kewenangan Berskala Lokal 